\title{
Beş Aylık Bebekte Deri Tutulumu ile Saptanan Langerhans Hücreli Histiyositoz: Olgu Sunumu
}

\author{
Langerhans Cell Histiocytosis Manifested with Cutaneous Findings, in a Five-months-old Baby: Case Report
}

\section{Merih Tepeoğlu ${ }^{1}$, Alev Ok Atılgan ${ }^{1}$, Seda Pürnak ${ }^{2}$, Nesibe Deren Özcan ${ }^{2}$, Özlem Özen ${ }^{1}$}

${ }^{1}$ Başkent Üniversitesi Tıp Fakültesi Patoloji AD, Ankara, Türkiye

${ }^{2}$ Başkent Üniversitesi Tıp Fakültesi Deri ve Zührevi Hastalıklar AD, Ankara, Türkiye

\section{ÖZET}

Langerhans hücreli histiyositoz, histiyositlerden köken alan ve patogenezi tam olarak bilinmeyen, aktive Langerhans hücrelerinin klonal çoğalması ile karakterize, nadir görülen bir hastalıktır. Çok farklı klinik prezentasyonlarla karşımıza çıkan bu hastalık, çoğunlukla çocukluk yaş grubunda görülür. En sık kemik, kemik iliği ve ikinci sıklıkla da deri tutulumu gösteren langerhans hücreli histiyositoz, tutulum yerleri ve klinik prezentasyonlarına göre dört alt gruba ayrılır; Letterer-Siwe hastalığı, Hand-Schüller-Christian hastalığı, eozinofilik granülom ve konjenital Self-Healing Retikulohistiyositoz. Kesin tanı langerhans hücresinin elektron mikroskopik olarak gösterilmesi veya immünohistokimyasal olarak CD1a yüzey antijeninin gösterilmesi ile konur. $\mathrm{Bu}$ yazıda seboreik dermatit tanısı ile uzun dönem tedavi almış bir langerhans hücreli histiyositoz olgusu sunulmuştur.

Anahtar Sözcükler: Histiyositoz, çocuk, deri

Geliş Tarihi: 28.02.2013
Kabul Tarihi: 03.06.2013

\section{ABSTRACT}

Langerhans cell histiocytosis is a rare disease, characterized by a clonal proliferation of activated Langerhans cells. The disease has many different clinical presentations and occurs mostly in childhood. Skin involvement is the second most common involvement of langerhans cell histiocytosis after the bone and bone marrow. The disease has four subgroups according to the clinical manifestation and organ involvement; LettererSiwe, Hand-Schüller-Christia, eosinophilic granuloma and congenital selfhealing langerhans cell histiocytosis. Accurate diagnosis is made by showing langerhans cells by electron microscopy or by detecting CD1a surface antigen by immunohistochemistry. We describe a case of langerhans cell histiocytosis that were falsely diagnosed and treated as seborrheic dermatititis.

Key Words: Histiocytosis, child, skin

Received: 02.28 .2013

Accepted: 06.03.2013

\section{Giriş}

Langerhans hücreli histiyositoz (LHH) tipik olarak infant ve çocukları etkileyen mononükleer fagositer sistem hücreleri tarafından organların infiltrasyonu ve monoklonal proliferasyonu ile karakterize nadir bir hastalıktır (1). Hastalık, klinik olarak çok değişken bir seyir gösterir. En fazla kemik, kemik iliği, cilt, lenf nodları, akciğer, karaciğer, dalak ve meninksler tutulur. Tutulum yerleri ve klinik prezentasyonlarına göre dört gruba ayrılır; Letterer-Siwe hastalığı, Hand-Schüller-Christian hastalığı,eozinofilik granülom ve konjenital Self-Healing Retikulohistiyositoz. Kesin tanı langerhans hücresinin elektron mikroskopik olarak gösterilmesi veya immünohistokimyasal olarak CD1a yüzey antijeninin gösterilmesi ile konur (1-3). Burada, uzun dönem tanı konamayan ve seboreik dermatit tanısıyla tedaviler verilen beş aylık bebek olgusu sunulmuştur.

\section{OLGU SUNUMU}

Beş aylık erkek bebek, kıvrım bölgelerinde, gövde ve kaşlarda 2 aydır devam eden, son 3 haftadır şiddetlenen kızarıklık ve kabuklanma nedeniyle Deri ve Zührevi Hastalıklar Polikliniği'ne başvurdu. Daha önce pişik tanısı ile antifungal, antibiyotikli ve kortikosteroidli kremler ile ıslak pansumanlar kullanılmış ancak fayda görmemişti. Çok su içme, sık idrara çıkma, büyüme geriliği, ateş, kusma, ishal, boyun ve koltuk altında şişlikler gibi ek şikayetleri yoktu. Sağlıklı 27 yaşındaki annenin ilk gebeliğinden 40 haftalık sezaryen ile $3500 \mathrm{~g}$ doğan hastanın özgeçmişinde ve soygeçmişinde özellik saptanmadı. 
Dermatolojik muayenede; perianal, inguinal, aksillar bölgelerde, karın kıvrımı ve çevresinde eritemli yer yer erode yamalar, sakral bölgede kaşlarda ve saçlı deride eritemli zeminde sarı skuamlı papüller ve yer yer plaklar izlendi (Resim 1). Fizik muayenede; periferik lenf nodu ve hepatosplenomegali izlenmedi. Akrodermatitis enteropatika ön tanısı ile bakılan çinko düzeyi normal sınırlarda idi $(97 \mu \mathrm{g} / \mathrm{dl})$.

Hastadan alınan deri punch biyopsi materyalinin histopatolojik incelemesinde üst dermiste gruplar halinde infiltrasyon oluşturan, yer yer epidermis içine invazyon gösteren ve epidermiste yuvalar oluşturan tümöral lezyon görüldü (Resim 2). Lezyonu oluşturan hücreler ovoid şekilli, geniş eozinofilik sitoplazmalı idi. Ekzantrik yerleşen hücre nükleuslarının bir kısmında nükleer çentiklenme ve böbreksi görünüm dikkati çekti (Resim 3). Hücresel atipi veya mitotik etkinlik artışı saptanmadı. Yapılan immünhistokimyasal çalışma sonucunda lezyonu oluşturan bu hücrelerin S100 ve CD1a antikorları (Resim-4) ile reaksiyon gösterdiği görüldü. Ayırıcı tanıya yönelik yapılan HMB-45, Melan-A, CD 68, CK 7 ve CEA antikorları ile reaksiyon saptanmadı. Bu bulgularla Langerhans hücreli histiyositozis tanısı konuldu. Hasta ileri inceleme amacıyla pediatrik onkoloji bölümüne yönlendirildi. Ancak hasta bu süreçte takipten çıkarıldı.

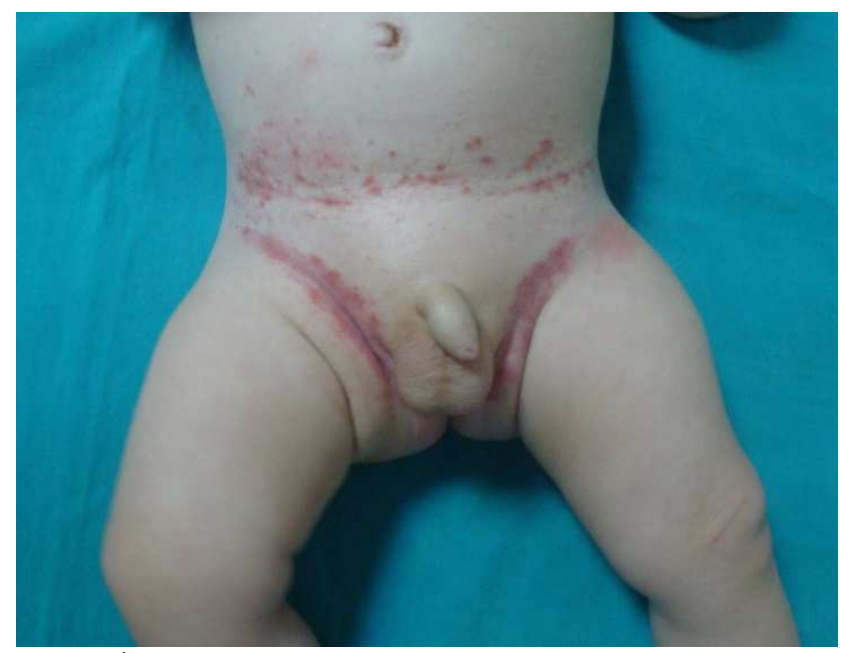

Resim 1. İnguinal bölgede yer yer erozyonların izlendiği ince skuamlı eritemli plaklar ve alt abdominal bölgede multipl kurutlu ve eritemli papüller

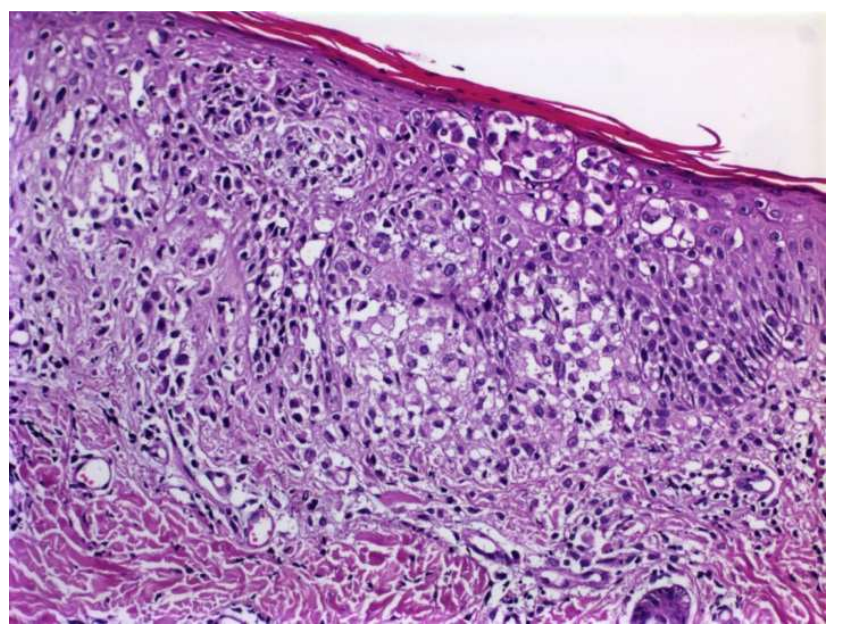

ve epidermiste yuvalar halinde infiltrasyon olusturan tümöral oluşum (H\&E, x200)

\section{TARTIŞMA}

LHH, etyopatogenezi bilinmeyen anormal histiyosit proliferasyonu sonucu gelişen, nadir görülen bir hastalık grubudur. Hastalık yeni doğan döneminden geç yaşlara kadar herhangi bir yaşta ortaya çıkabilir. Yıllık insidansı milyonda 3-4 olarak tahmin edilmektedir (1-3).
LHH'da izlenen histiyositik hücre grubu langerhans hücreleri olup, bu hücreler epidermisin kemik iliği kökenli dendritik hücreleridir. Intrasitoplazmik organeller olan Birbeck granüllerine, Class II MHC moleküllerine ve CD1a glikoproteinine sahip olmaları en karakteristik özellikleridir (1-3). Langerhans hücreleri vücudun en güçlü antijen sunan hücrelerindendir ve ciltten giren yabancı antijenlerin tanınmasında çok önemli bir görev üstlenmektedir. Epidermis dışında bukkal mukoza, vajina ve akciğerlerde de bulunurlar $(3,4)$.

Hastalık ilk kez, 1953 yılında, bilinmeyen etyolojisi nedeniyle Histiyositoz X adı ile tanımlanmıștır. Daha sonra 1985 yılında da ilk defa LHH adı ile anılmaya başlamıştır $(3,4)$. Hastalığın doğal seyri çok değişkendir. En sık kemik tutulumu (yaklaşık hastaların \%80'inde) görülmektedir. İkinci sıklıkla deri (\%30-60) tutulumu izlenmektedir. Hastaların \%10'unda tek tutulum yeri olarak deri karşımıza çıkmaktadır. Deri tutulumu en sık papüloskuamöz, hemorajik bir lezyon şeklinde olup, saçlı deri, gövde ve kıvrım yerlerinde bulunur. Lezyonlar çoğunlukla seboreik dermatit ile karışırlar. Lezyonlar skarlaşarak ve yerlerinde pigmentasyon bırakarak iyileşirler. Hastaların klinik seyri, tutulan organa ve etkilenme derecesine göre farklılıklar göstermektedir (3-5).

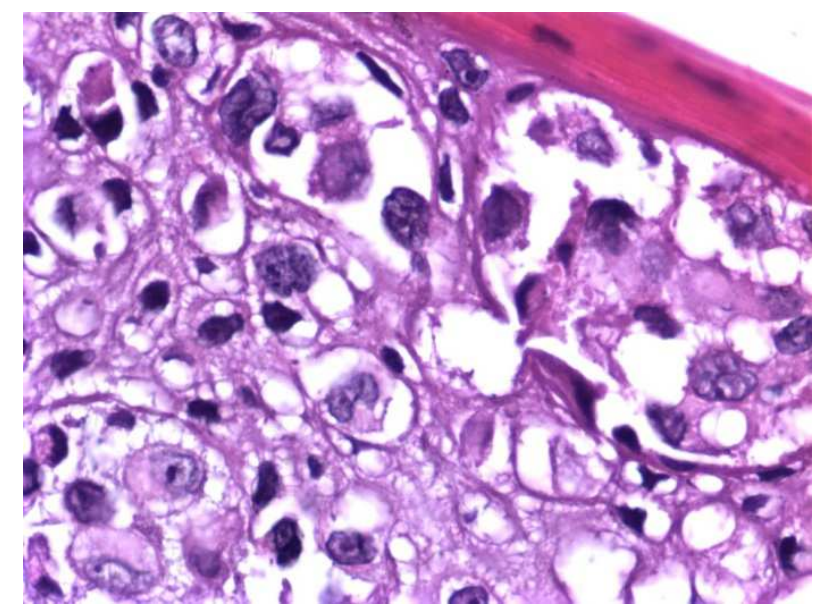

Resim 3. Tümörü oluşturan hücre nükleuslarında dikkati çeken çentiklenme ve böbreksi görünüm (H\&E, x1000)

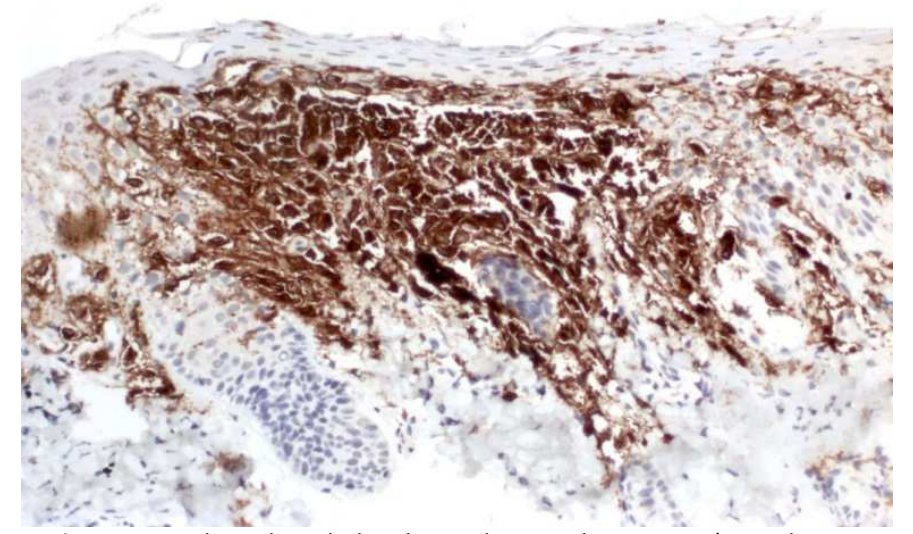

Resim4. Tümör hücrelerinde karakteristik CD 1a boyanması (CD1a boyası, $\mathrm{x} 100)$

Büyük çocuklarda genellikle kemik tutulumu ile lokal şişlik, ağrı ve fonksiyon bozukluğunun eşlik ettiği lokalize form görülürken, iki yaş altı çocuklarda ise, organ disfonksiyonunun da eşlik ettiği sistemik tutulum görülmektedir. Tutulum yerleri ve klinik bulgulara göre dört alt gruba ayrılır; Eozinofilikgranülom, Hand-Schüler- Christian, Letterer-Siwe ve Konjenital Self-Healing Retikulohistiyositoz (1-4). Bizim olgumuz, yaygın deri lezyonları ile karakterize olup, hastalığın klinik alt gruplarından Letterer-Siwe ile uyumluluk göstermektedir. 
Hastalığın tedavisinde, izole lezyonlar için küretaj, kemoterapi, düşük doz radyoterapi uygulanır. Multifokal tutulumda ise sistemik kemoterapi (etoposid veya vinblastin) uygulanır (4-7).

Kesin tanı biyopsi ile konur. Histopatolojik olarak, çentikli (indented/reniform) nükleuslu, belirgin eozinofilik sitoplazmalı, geniş ovoid hücrelerin gruplar ya da adalar oluşturmasıyla karakterizedir. Hücreler çoğunlukla epidermisin hemen altında, yüzeyel dermiste izlenir, ancak çok az bir kısmı derin dermise ilerler. Bazı alanlarda langerhans hücreleri, epidermise invazyon göstererek, küçük topluluklar oluşturabilir.

Langerhans hücre infiltrasyonuna, değişik oranlarda iltihabi hücreler de eşlik eder. Letterer-Siwe hastalığında, infiltrat çoğunlukla langerhans hücresi olmak üzere az sayıda nötrofil, eozinofil yada lenfosit içerirken, eozinofilik granülomda, eozinofil toplulukları infiltrasyonun baskın komponentini oluşturmaktadır. Buna karşılık Hand-Schüller-Christian hastalığında ise çok sayıda dev hücre oluşumu izlenmektedir. LHH tanısı, histopatolojik olarak izlenen bu bulgulara ek olarak immünhistokimyasal olarak CD 1a antijeni ekspresyonunun gösterilmesi ile ya da elektron mikroskopik olarak Birbeck granüllerinin saptanması ile konur (4-7).

Bizim olgumuzda olduğu gibi intraepidermal tutulum olan olgularda, histopatolojik olarak ayırıcı tanıda aklımızda tutulması gereken üç önemli antite bulunmaktadır; malign melanom, mikozis fungoides ve Paget hastalığı.

Malign melanom, atipik melanositlerin epidermis içerisinde ve/veya dermiste proliferasyonu ile karakterize olan ve oldukça agresif seyreden bir malignitedir. Histopatolojik olarak epidermis içerisinde infiltrasyon oluşturan hücre grupları izlendiğinde, ilk dışlanması gereken tanı malign melanomdur. Melanosit kökenini göstermenin en kesin yolu da immünohistokimyadır. HMB-45 ve Melan-A, sensitivitesi oldukça yüksek melanositik markerlardır (1).

Paget hastalığı, geniş nükleuslu, belirgin nükleol ve soluk-eozinofilik sitoplazmalı neoplastik hücrelerin epidermis boyunca dağılması ile karakterize, meme ve meme dışı dokularda görülebilen bir malignitedir. Paget hastalığı, benzer histolojik görünümleri sebebiyle, LHH ile karışabilir. Kesin ayırım immünhistokimyasal olarak yapılan EMA ve CEA ile mümkün olmaktadır. Paget hastalığında, epidermis içerisinde izlenen atipik hücreler, EMA ve CEA ile pozitif boyanmaktadır (1).
Mikozis fungoides, derinin en sık görülen T hücreli lenfoması olup, yama, plak ve tümör evreleri olmak üzere çeşitli klinik prezentasyonlarla karşımıza çıkabilir. Erken dönem (yama dönemi) lezyonlarında histopatolojik olarak epidermotropizm gösteren tek-tük atipik lenfositler izlenir. Plak ve tümör evrelerinde ise, epidermis içinde yuvalar oluşturmuş atipik lenfositlerin yanı sıra, dermiste de belirgin lenfoidhücre popülasyonu görülür. İmmünhistokimyasal olarak yapılan T hücre belirteçleri (CD3, CD5 gibi) ayırıcı tanıda önemlidir (1).

LHH'un önemli ayırıcı tanılarından biri de non-Langerhans hücreli histiyositozlardır. Epidermal infiltrasyon oluşturmaksızın, dermal tutulum göstermeleri ve immünhistokimyasal profilleri ( $C D 68$ pozitif, $C D$ 1a negatif) ile $\mathrm{LHH}^{\prime}$ dan ayrılırlar (1).

Günlük pratikte çok fazla karşımıza çıkmayışı ve bu nedenle de ilk aşamada aklımıza gelmemesi nedeniyle, bu tür hastalar tanı almada çoğunlukla gecikebilmektedir. Özellikle çocukluk yaş grubunda dirençli seyreden seboreik dermatitler de LHH mutlaka akla gelmeli ve biyopsi ile değerlendirme yapılmalıdır. Hastalarda deri tutulumundan yıllar sonra kemik, kemik iliği, karaciğer, akciğer gibi diğer organ tutulumları görülebilir. Bu nedenle deri tutulumunun saptanması, hastaların takibi ve tedavisi açısından son derece önemlidir.

\section{Çıkar Çatıșması}

Yazarlar herhangi bir çıkar çatışması bildirmemişlerdir.

\section{KAYNAKLAR}

1.Weedon D. Cutaneous infiltrates-non-lymphoid. In: Weedon D ed. Weedon's Skin Pathology. 3rd ed. Elsevier, 2010: 937-71.

2.Recent advances in the understanding of Langerhans cell histiocytosis. BadalianVery G, Vergilio JA, Degar BA, Rodriguez-Galindo C, Rollins BJ. Br J Haematol 2012; 156:163-72.

3.Park L, Schiltz C, Korman N. Langerhans cell histiocytosis. J Cutan Med Surg 2012;16:45-9.

4.Satter EK, High WA. Langerhans cell histiocytosis: a review of the current recommendations of the Histiocyte Society. Pediatr Dermatol 2008; 25: 291-5

5.Lau L, Krafchik B, Trebo M, Weitzman S. Cutaneous Langerhans Cell Histiocytosis in Children Under One Year. Pediatr Blood Cancer 2006;46: 66-71.

6.Gupta V, Bansal M. Cutaneous Langerhans Cell Histiocytosis. Indian Pediatrics 2012;49:79.

7.Huang JT, Mantagos J, Kapoor R, Schmidt B, Maguiness S. Langerhans cell histiocytosis mimicking molluscum contagiosum. J Am Acad Dermatol 2012;67: 117-8. 